\title{
Endothelial arginase II and atherosclerosis
}

\author{
Sungwoo Ryoo ${ }^{1}$, Dan E. Berkowitz ${ }^{2}$, and Hyun Kyo Lim $^{3}$ \\ ${ }^{1}$ Division of Biology, Kangwon National University, Chuncheon, Korea, ${ }^{2}$ Department of Anesthesiology and Critical Medicine and \\ Biomedical Engineering, The Johns Hopkins Medical Institutes, Baltimore, MD, USA, ${ }^{3}$ Department of Anesthesiology and Pain \\ Medicine, Yonsei University Wonju College of Medicine, Wonju, Korea
}

Atherosclerotic vascular disease is the leading cause of morbidity and mortality in developed countries. While it is a complex condition resulting from numerous genetic and environmental factors, it is well recognized that oxidized low-density lipoprotein produces pro-atherogenic effects in endothelial cells (ECs) by inducing the expression of adhesion molecules, stimulating EC apoptosis, inducing superoxide anion formation and impairing protective endothelial nitric oxide (NO) formation. Emerging evidence suggests that the enzyme arginase reciprocally regulates NO synthase and NO production by competing for the common substrate L-arginine. As oxidized LDL (OxLDL) results in arginase activation/upregulation, it appears to be an important contributor to endothelial dysfunction by a mechanism that involves substrate limitation for endothelial NO synthase (eNOS) and NO synthesis. Additionally, arginase enhances production of reactive oxygen species by eNOS. Arginase inhibition in hypercholesterolemic $\left(\mathrm{ApoE}^{-/-}\right)$mice or arginase II deletion $\left(\mathrm{ArgII}^{-/-}\right)$mice restores endothelial vasorelaxant function, reduces vascular stiffness and markedly reduces atherosclerotic plaque burden. Furthermore, arginase activation contributes to vascular changes including polyamine-dependent vascular smooth muscle cell proliferation and collagen synthesis. Collectively, arginase may play a key role in the prevention and treatment of atherosclerotic vascular disease. (Korean J Anesthesiol 2011; 61:3-11)

Key Words: Arginase, Atherosclerosis, Endothelial dysfunction, Endothelial nitric oxide synthase, Vascular smooth muscle cell.

\section{Introduction}

Although age-adjusted deaths resulting from atherodegenerative cardiovascular disease have decreased [1], the absolute number of deaths due to cardiovascular disease is projected to double over the next 50 years, primarily due to a disproportionate increase of the elderly in the population [2]. Considering that $40 \%$ of all deaths occur as a result of cardiovascular disease and that 65 million people in the United States of America (20\% of the country's population)

Received: June 13, 2011. Revised: July 4, 2011. Accepted: July 4, 2011.

Corresponding author: Hyun Kyo Lim, M.D., Department of Anesthesiology and Pain Medicine, Yonsei University Wonju College of Medicine, 162, Ilsan-dong, Wonju 220-701, Korea. Tel: 82-33-741-1536, Fax: 82-33-742-8198, E-mail: hyunkyolim@yonsei.ac.kr

(c) This is an open-access article distributed under the terms of the Creative Commons Attribution Non-Commercial License (http:// creativecommons.org/licenses/by-nc/3.0/), which permits unrestricted non-commercial use, distribution, and reproduction in any medium, provided the original work is properly cited. 
are affected by cardiovascular disease, the burden as a result of this disease on healthcare systems will escalate enormously [3]. Currently costing $\$ 350$ billion a year in the United States, the economic impact is also staggering. Worldwide, including non-industrialized countries, cardiovascular disease is the leading cause of death with 17 million cardiovascular diseaseassociated deaths per year [4]. Thus, despite the introduction of statins and focus on risk modifications, there is an urgent need for the identification of targets and development of therapeutic biomolecules against atherosclerotic disease (Fig. 1).

\section{Endothelium Function and OxLDL in the Vascular System}

The endothelium as a blood barrier plays a major role in the regulation of vascular homeostasis by maintaining the balance between vasoconstriction and vasodilation, as well as inhibiting and stimulating smooth muscle cell proliferation and migration. Endothelial dysfunction causing damage to the arterial wall is now considered an early marker for atherosclerosis, which induces attachment of monocytes to the endothelium, increases the permeability through the endothelial barrier and initiates oxidative modification of low-density lipoproteins. Modified LDL to oxidized LDL (OxLDL) particles are initially engulfed by macrophages, which utilize scavenger receptors on their surfaces, leading to foam cell formation. Formation of foam cells are indicative of the development of atherosclerosis [5].
Moreover, OxLDL appears to have potentially pro-atherogenic effects by inducing the expression of adhesion molecules on endothelial cells (ECs) [6], stimulating ECs apoptosis [7], inducing superoxide anion formation from NADPH oxidase, uncoupling endothelial nitric oxide synthase (eNOS) [8] and impairing endothelial nitric oxide (NO) formation, which is a major vasoprotective molecule released from the endothelium [9]. The responses to OxLDL in the endothelium are mediated by binding to the lectin-like OxLDL receptor-1 (LOX-1) [10], which activates multiple signaling cascades involving MAPK kinase $[11,12]$, protein kinase $C[13,14]$ and protein kinase $B$ [15]. OxLDL increases caveolin I expression and interaction of NOS with this protein impairs NO formation [16]. Furthermore, OxLDL modulates PKC activity and expression and this family of kinases has been shown to acutely attenuate eNOSdependent NO production and to promote eNOS uncoupling during prolonged exposure times [17]. In hypercholesterolemia, supplementation of L-arginine improves endothelialdependent relaxation and NO production $[18,19]$. L-arginine also attenuates the development of atherosclerosis [20] and normalizes leukocytes adhesion [21] in hypercholesterolemia. Also hypercholesterolemia favors the accumulation of asymmetrical dimethyl-L-arginine (ADMA), a competitive inhibitor to L-arginine of eNOS in monkeys [22]. OxLDL increases the activity of the S-adenosylmethionine-dependent protein arginine methyltransferases [22], which generate ADMA from L-arginine. Moreover, OxLDL decreases the activity of the

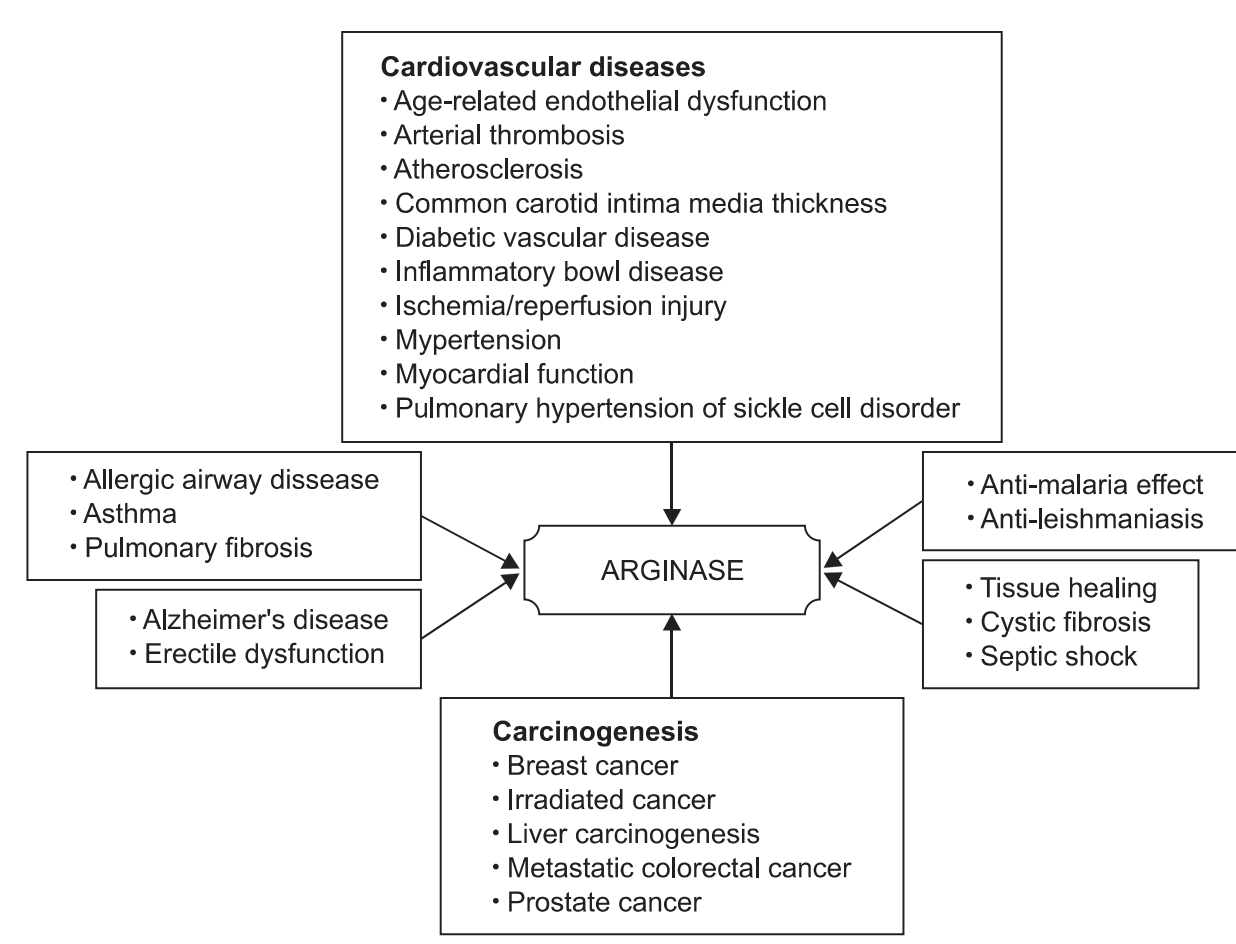

Fig. 1. Arginase inhibition and its therapeutic effects on diseases. Arginase is a prime therapeutic target protein predominantly emphasized by its role in asthma, cardiovascular and carcinogenic diseases. Furthermore, its application has been extended to preventing the progress of pulmonary fibrosis and erectile dysfunction. Focusing on cardiovascular diseases, atherosclerosis, hypertension, diabetic vascular disease and ischemia/reperfusion injury are the largest drug markets, occupying at least $25 \%$ of the total therapeutic market. 
ADMA-degrading dimethylarginine dimethylaminohydrolase [23]. Therefore, OxLDL is a strong inducer of endothelial dysfunction, a state in which the endothelium produces superoxide anions rather than NO.

NO is derived from the substrate L-arginine by the action of eNOS in the presence of several co-factors including NADPH, BH4, FMN and FAD. eNOS is the enzyme constitutively expressed in the endothelium and its activity is regulated by both chemical agonists and mechanical forces (shear stress). Agonists increase intracellular $\mathrm{Ca}^{2+}$ concentrations through G-protein coupled receptors (GPCR) and increase activity through a $\mathrm{Ca}^{2+}$-calmodulin dependent mechanism. In contrast, shear stress activates NOS by phosphorylation through the Akt/PKB pathway which is $\mathrm{Ca}^{2+}$ independent $[24,25]$. Imbalance in the L-arginine/eNOS pathway to produce NO has been demonstrated to be critically important in a variety of pathophysiological conditions. Alternations in NO signaling have been shown in both animal models and human subjects with hypertension [26], diabetes [27], hypercholesterolemia $[28,29]$, heart failure [29] and atherosclerosis [30].

\section{Arginase and Its Expression}

Arginase is well demonstrated as an important enzyme in the last step of the urea cycle, which is the detoxification pathway for high concentration of ammonia by hydrolyzing L-arginine to ornithine and urea. There are two described isoforms, arginase I and II, encoded by different genes [31,32]. Arginase I has been known as the hepatic isoform, catalyzing the final step of the urea cycle, although recent studies demonstrate that arginase I can be induced by LPS, IL-13 and hypoxia in a wide variety of cells and tissues [33-37]. Arginase II has been referred to as the extrahepatic isoform and is inducible by a variety of factors: LPS, TNF $\alpha$, interferon $\gamma$, 8-bromo-cGMP and hypoxia $[34,35,38,39]$. The extrahepatic isoform is widely distributed in numerous tissues. Additionally, arginase II provides ornithine for the synthesis of polyamines and L-proline, controlling cell proliferation, differentiation and repairing tissues following injury via ornithine decarboxylase $[40,41]$. Arginase II also contains a putative mitochondrial targeting sequence in the amino terminus and is thought to be confined primarily to the mitochondria $[42,43]$. It has recently been found that arginase reciprocally regulates NO production in ECs, that arginase is increased in the endothelium of ageing rats and that the inhibition or anti-sense knockdown of arginase I restores NO signaling and improved endothelial function in the vasculature of old rats $[44,45]$. In addition, the role of arginase in endothelial dysfunction has been extended to various cardiovascular disorders of animal models such as aging [44], ischemia-reperfusion-induced endothelial dysfunction [46], aortic coarctation hypertension [47], salt-induced hypertension and atherosclerosis [48]. In the penis, arginase II reciprocally regulates NO production and modulates erectile function. In the diabetic human corpus cavernosum, increased arginase II expression negatively regulates NO production and possibly contributes to erectile dysfunction [49].

Arginase II activity in OxLDL-stimulated human aortic endothelial cells (HAECs) is increased by two distinct mechanisms: (1) a novel early posttranslational event involving the release of the enzyme from microtubule association, resulting in activation; (2) transcriptional upregulation [50]. In thrombin-stimulated human umbilical vein endothelial cells, arginase II activity is increased through the Rho/ROCK pathway and the inhibitors Y-27632 and HA-1077 prevent arginase II activation without affection protein levels [51]. In LPS-treated macrophages, MAPK phosphatase-1 deficiency negatively regulates urea formation via greater expression of inducible NOS (iNOS) and NO production, although the overexpression or knockout of MKP-1 has no any substantial effect on the expression of arginases [52].

\section{Arginase and Reciprocal Regulation of Nitric Oxide}

The three isoforms of NOS, eNOS, iNOS, and neuronal NOS (nNOS), produce NO from the substrate L-arginine, which is converted to L-ornithine and urea by the action of arginase. An emerging paradigm in NO biology is the concept that arginase, an enzyme that shares L-arginine as a substrate, reciprocally regulates NOS activity by competing for the substrate. Thus, arginase activity can effectively regulate NO-dependent processes by depleting the substrate pool available for NO biosynthesis (Fig. 2).

Arginase upregulation/activation impairs NO production by NOS isoforms and induces endothelial dysfunction associated with systemic hypertension $[48,53]$. Furthermore, compelling evidence suggests that arginase upregulation may aggravate pulmonary hypertension $[54,55]$, a disease process known to be associated with impaired pulmonary vascular NO signaling. An increase in endothelial arginase activity contributes to the endothelial function and vascular stiffness associated with aging [44], although the isoform appears to be arginase I rather than arginase II. Increased arginase activity in aorta of $\mathrm{ApoE}^{-/-}$in mice is not correlated with an increase in arginase protein abundance. Arginase activation rather than an increase in protein abundance may be responsible for increased enzyme activity. In human aortic endothelial cells, the mechanism of increased arginase activity in response to OxLDL stimulation involves a rapid dissociation of the enzyme from the microtubular cytoskeletal structure, which appears 


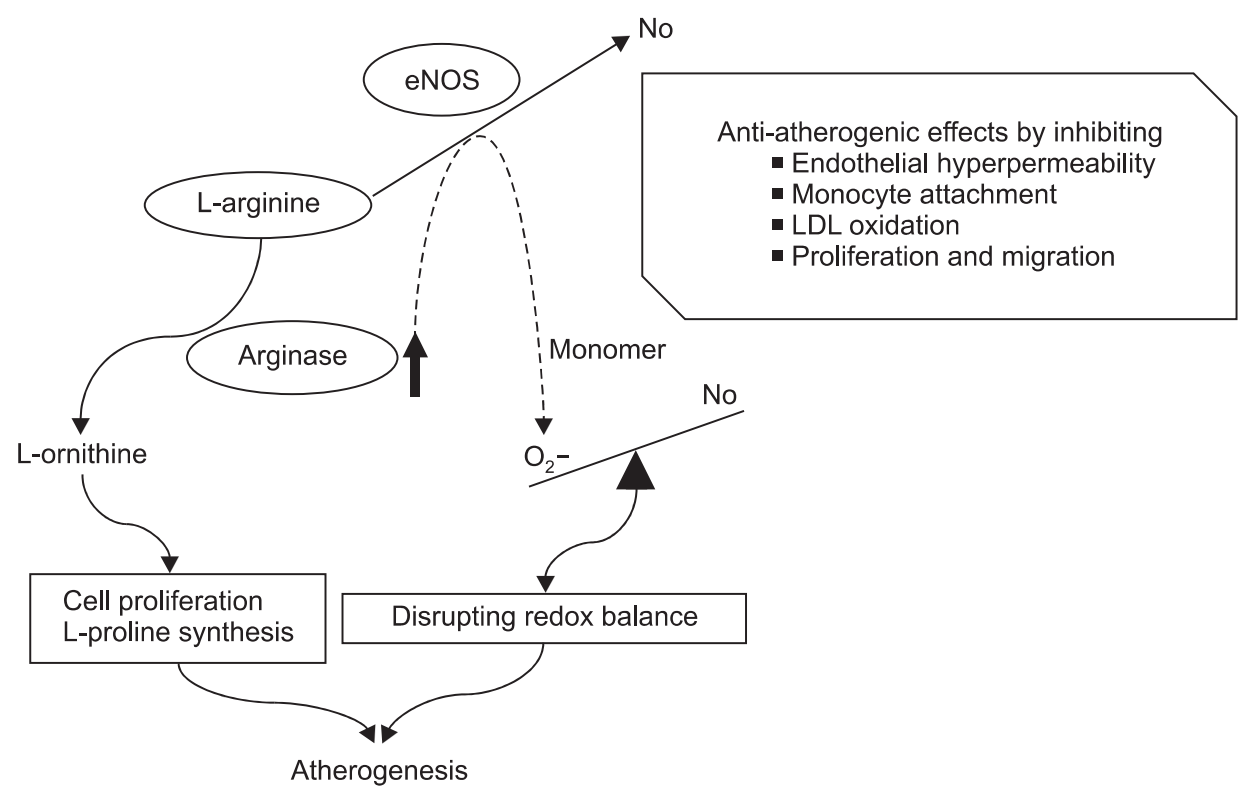

Fig. 2. Arginase roles in the atherogenic pathophysiology. Endothelial NOS catalyses L-arginine to L-citrulline and nitric oxide, which is an anti-atherogenic molecule produced in the endothelium. NO has been shown to have some protective effects by inhibiting endothelial hyperpermeability, monocyte attachment, the oxidative modification of low-density lipoproteins as well as the proliferation and migration of vascular smooth muscle cells. In endothelial cells (ECs), constitutively expressed arginase shares the common substrate, L-arginine. Arginase hydrolyzes L-arginine to urea and L-ornithine that is supplied for the synthesis of polyamines and L-proline. These are commonly used for cell proliferation and collagen synthesis which increases cross-linking in the extracellular matrix, leading to increases of vascular stiffness. Furthermore, increased arginase activity stimulates eNOS monomerization by depletion of their substrates and induces superoxide production by monomerized eNOS. Augmented superoxide production quickly disrupts the redox balance in ECs and leads to endothelial dysfunction. Therefore, arginase activation directly causes atherogenic vascular disease.

to constrain its activity [50]. This is not reflected in vivo. This observed difference may be the result of species differences. The concept of species variability is supported by Hayashi et al. [56] who demonstrated that both arginase I and II abundances are increased in the vasculature of rabbits that are fed a high cholesterol diet and that arginase II abundance is modulated by estrogen administration. Being consistent with the vasculature, arginase II expressed specifically in myocyte constrains nNOS activity in the rat cardiac myocyte in an isoform-specific manner [57]. Arginase inhibition increases basal contractility in isolated myocytes by a nNOS-dependent mechanism, although the supplementation of L-arginine has no effect on myocyte NO production or myocyte contractility. Thus, this observation suggests that L-arginine pools are very tightly controlled for availability by the enzymes, iNOS and arginase II, in the myocyte.

There appears to be at least 3 pools of L-arginine that are spatially confined and regulated by different transporters and enzymes $[58,59]$. Thus, local concentrations of L-arginine in microdomains in which NOS and/or arginase might be located may be limiting for NOS isoforms. This is the concept of the L-arginine paradox that is found in the mammalian organism by which L-arginine concentrations by far exceed
Km values of NOS. Therefore, additional L-arginine should not enhance NO formation. In vivo however, increasing L-arginine concentrations in plasma has been repeatedly shown to increase NO production.

With respect to enzymatic kinetics, the $\mathrm{Km}$ value of arginase is a range of $1-20 \mathrm{mM}$ for L-arginine and that of NOS is $1-5 \mu \mathrm{M}$. This result implies that comparing the substrate competition between the enzymes is not effective. However, the catalysis rate of these enzymes has shown that arginase has a Vmax of 1400 $\mu \mathrm{mol} / \mathrm{min} / \mathrm{mg}$, while NOS has a Vmax of $900 \mu \mathrm{mol} / \mathrm{min} / \mathrm{mg}$ [60]. As cellular conditions contain much higher concentration of L-arginine than the Km value for NOS, a direct comparison of the $\mathrm{Km}$ value is not a reliable measurement for the catalytic properties of these enzymes [60].

Recently, Topal et al. [61], demonstrated using pharmaceutical techniques that three L-arginine pools exist: 1) a freely exchangeable pool (pool I) with extracelluar L-arginine that is regulated by the cationic transporter (CAT-1) and depleted by exchanging the pool with cationic amino acid lysine, 2) a nonfreely exchangeable pool (pool II) with extracellular L-arginine that cannot depleted by L-lysine, and 3) extracellular L-arginine pools (pool III) present in ECs and mitochondrial arginase II which modulates NO synthesis through a nonfreely 
exchangeable L-arginine pool. According to recent increasing paradigms, not freely exchangeable L-arginine pool II is composed of two cytosolic microdomains that pool IIA appears functions of the recycling of citrulline to arginine by combined reactions of arginosuccinate synthetase and arginosuccinate lyase [62]. The remaining L-arginine pool IIB reveals a property that cannot be depleted by neutral amino acids such as histidine.

The direct mechanisms are not well understood regarding how arginase activity can regulate or effect eNOS activity on a molecular level. A recent concept is that eNOS coupling is responsible for NO production and that eNOS uncoupling induces superoxide generation which is confirmed with OxLDLstimulated ECs. Inhibition of arginase with S-(2-boronethyl)-Lcysteine (BEC) prevented the decrease in eNOS dimer bands. In addition, $\mathrm{N}$ (G)-nitro-L-arginine methyl ester (L-NAME) also prevented OxLDL-dependent decreases in dimer formation, and treatment of cells with L-arginine partially preserves eNOS dimer stability [63].

\section{ROS and the Vasculature}

Under normal physiologic conditions, the use of oxygen by cells of aerobic organisms generates potentially deleterious reactive oxygen metabolites. A chronic state of oxidative damage exists in cells because of an imbalance between pro-oxidants and antioxidants. With regard to blood vessels, vascular production of reactive oxygen species (ROS) and the subsequent reaction and scavenging of NO is thought to be an important mechanism of vascular dysfunction in atherosclerosis [64] and hypertension [65]. There are three major enzymatic sources for vascular ROS and the mitochondrial electron transport chain (ETS): NAD(P)H oxidase, xanthine oxidase (XO), and NOS [66]. The NAD(P)H oxidase system has been under intense investigation ever since its discovery in the vasculature and its importance in atherosclerosis with impaired-NO dependent vasodilator function has been recognized. It was originally demonstrated that the $\mathrm{NAD}(\mathrm{P}) \mathrm{H}$ oxidase system was expressed in the smooth muscle and adventitial cells (fibroblasts) of the vascular wall and that function of the enzyme could be enhanced by angiotensin II [67]. The upstream signaling mechanisms by which angiotensin II enhances ROS production have recently been uncovered and appear to be protein kinase C mediated [68]. This signaling is recognized to be important in forms of hypertension in which the rennin angiotensin system is activated [69]. Endothelial XO may also contribute to increased oxidative stress and endothelial function associated with disease processes such as diabetes [70].

The role of NOS-3 in the generation of ROS is critically dependent on the bioavailability of L-arginine. In physiological conditions, L-arginine availability, at least when measured extracellularly, does not appear to be rate-limiting in the production of NO [71]. However, L-arginine concentrations in intracellular microdomains remain unknown. In fact, it has been shown that the administration of L-arginine restores, at least in part, the physiologic activity of NO in experimental hypercholesterolemia and hypertension [72]. The depletion of L-arginine leads to a derangement of the oxidase/reductase domains of NOS. Thus, NOS-3, when activated in an arginine depleted environment, is still able to receive electrons from NADPH and donate them to the substrate $\mathrm{O}_{2}$, resulting in one electron reduction to form $\mathrm{O}_{2}{ }^{-}$. It is established that $\mathrm{O}_{2}{ }^{-}$is produced by endothelial cells along with $\mathrm{NO}$ and that L-arginine availability may determine the ratio of $\mathrm{O}_{2}{ }^{-}$to $\mathrm{NO}$ produced. In addition, L-NAME can inhibit $\mathrm{O}_{2}{ }^{-}$generation by blocking NOS-3 activity through binding to the active site and decreasing electron flux to the heme site of the enzyme [73].

\section{NO, Vascular Stiffness and Atherosclerosis}

The role of vascular stiffness in hypertension, in vascular disease associated with renal impairment and in the vascular changes that accrue with age is well documented [74-79]. Moreover, increased vascular stiffness represents a marker of increased vascular risk [79-83]. Although age is now recognized as the dominant cardiovascular risk factor, vascular stiffness is increasingly recognized as an even more powerful risk predictor because of the variability in vascular changes that occur with age and because vascular stiffness develops in non-age related conditions [84].

Atherosclerosis is primarily a disease that accrues with age. There is evidence that vascular stiffness is correlated with indices of advanced atherosclerotic disease in animal, human neurological and cardiac studies. It is unclear whether vascular stiffness perturbations reflect atherosclerosis or an age/pressure related phenomenon. However, mechanistically, certain studies have demonstrated a correlation between vascular stiffness and disturbances in lipid metabolism [85-87]. In its initial phases, atherosclerosis manifests itself by disturbances in EC function, NO bioavailability and oxidant stress, as demonstrated by impaired forearm [88] and coronary [89] endothelial-dependent vasodilatation. NO bioavailability has also been clearly demonstrated to modulate arterial stiffness [90]. However, vessel stiffness can also modulate endothelial cell signaling in response to luminal stimuli and the resulting NO release [91]. In clinical studies, high-resolution carotid ultrasonography has been used to obtain measurements of the thickness of the intima and media of the carotid arteries [92]. Previous studies have shown cross-sectional associations between common carotid artery intima-media thickness and cardiovascular risk 
factors, the prevalence of cardiovascular disease [93] and the involvement of other arterial beds with atherosclerosis [94]. Changes in commoncarotidartery intima-media thickness have also been adopted as a surrogate endpoint for determining the success of interventions that lowers the levels of lowdensity lipoprotein cholesterol [95]. Increases in intima-media thickness of the carotid artery, as measured non-invasively by ultrasonography, are directly associated with an increased risk of myocardial infarction and stroke in older adults without a history of cardiovascular diseases [93].

\section{Conclusions}

Inhibition of endothelial arginase or deletion of the arginase II gene enhances NO production, restores endothelial function and aortic compliance, and reduces plaque burden. Arginase II represents a novel risk factor-independent target for the prevention and treatment of atherosclerotic vascular disease.

\section{References}

1. Beller GA. Coronary heart disease in the first 30 years of the 21st century: challenges and opportunities: The 33rd Annual James B. Herrick Lecture of the Council on Clinical Cardiology of the American Heart Association. Circulation 2001; 103: 2428-35.

2. Foot DK, Lewis RP, Pearson TA, Beller GA. Demographics and cardiology, 1950-2050. J Am Coll Cardiol 2000; 35(5 Suppl B): B6680.

3. Heart Disease and stroke statistics-2004. Paper presented at American Heart Association. Dallas, Texas. 2003

4. Bonow RO, Smaha LA, Smith SC Jr, Mensah GA, Lenfant C. World Heart Day 2002: the international burden of cardiovascular disease: responding to the emerging global epidemic. Circulation 2002; 106: 1602-5.

5. Ross R. Atherosclerosis--an inflammatory disease. N Engl J Med 1999; 340: 115-26.

6. Khan BV, Parthasarathy SS, Alexander RW, Medford RM. Modified low density lipoprotein and its constituents augment cytokineactivated vascular cell adhesion molecule-1 gene expression in human vascular endothelial cells. J Clin Invest 1995; 95: 1262-70.

7. Dimmeler S, Haendeler J, Galle J, Zeiher AM. Oxidized lowdensity lipoprotein induces apoptosis of human endothelial cells by activation of CPP32-like proteases. A mechanistic clue to the 'response to injury' hypothesis. Circulation 1997; 95: 1760-3.

8. Galle J, Bengen J, Schollmeyer P, Wanner C. Impairment of endothelium-dependent dilation in rabbit renal arteries by oxidized lipoprotein(a). Role of oxygen-derived radicals. Circulation 1995; 92: 1582-9.

9. Kugiyama K, Kerns SA, Morrisett JD, Roberts R, Henry PD. Impairment of endothelium-dependent arterial relaxation by lysolecithin in modified low-density lipoproteins. Nature 1990; 344: 160-2.

10. Sawamura T, Kume N, Aoyama T, Moriwaki H, Hoshikawa H, Aiba Y, et al. An endothelial receptor for oxidized low-density lipoprotein.
Nature 19976; 386: 73-7.

11. Mehta JL, Chen J, Yu F, Li DY. Aspirin inhibits ox-LDL-mediated LOX-1 expression and metalloproteinase-1 in human coronary endothelial cells. Cardiovasc Res 2004; 64: 243-9.

12. Li D, Singh RM, Liu L, Chen H, Singh BM, Kazzaz N, et al. OxidizedLDL through LOX-1 increases the expression of angiotensin converting enzyme in human coronary artery endothelial cells. Cardiovasc Res 2003; 57: 238-43.

13. Ohgushi M, Kugiyama K, Fukunaga K, Murohara T, Sugiyama S, Miyamoto E, et al. Protein kinase $\mathrm{C}$ inhibitors prevent impairment of endothelium-dependent relaxation by oxidatively modified LDL. Arterioscler Thromb 1993; 13: 1525-32.

14. Sugiyama S, Kugiyama K, Ohgushi M, Fujimoto K, Yasue H. Lysophosphatidylcholine in oxidized low-density lipoprotein increases endothelial susceptibility to polymorphonuclear leukocyteinduced endothelial dysfunction in porcine coronary arteries. Role of protein kinase C. Circ Res 1994; 74: 565-75.

15. Nihei S, Yamashita K, Tasaki H, Ozumi K, Nakashima Y. Oxidized low-density lipoprotein-induced apoptosis is attenuated by insulinactivated phosphatidylinositol 3-kinase/Akt through p38 mitogenactivated protein kinase. Clin Exp Pharmacol Physiol 2005; 32: 2249.

16. Everson WV, Smart EJ. Influence of caveolin, cholesterol, and lipoproteins on nitric oxide synthase: implications for vascular disease. Trends Cardiovasc Med 2001; 11: 246-50.

17. Fleming I, Mohamed A, Galle J, Turchanowa L, Brandes RP, Fisslthaler B, et al. Oxidized low-density lipoprotein increases superoxide production by endothelial nitric oxide synthase by inhibiting PKCalpha. Cardiovasc Res 2005; 65: 897-906.

18. Girerd XJ, Hirsch AT, Cooke JP, Dzau VJ, Creager MA. L-arginine augments endothelium-dependent vasodilation in cholesterol-fed rabbits. Circ Res 1990; 67: 1301-8.

19. Drexler H, Zeiher AM, Meinzer K, Just H. Correction of endothelial dysfunction in coronary microcirculation of hypercholesterolaemic patients by L-arginine. Lancet 1991; 338: 1546-50.

20. Böger RH, Bode-Böger SM, Brandes RP, Phivthong-ngam L, Böhme M, Nafe R, et al. Dietary L-arginine reduces the progression of atherosclerosis in cholesterol-fed rabbits: comparison with lovastatin. Circulation 1997; 96: 1282-90.

21. Brandes RP, Brandes S, Boger RH, Bode-Boger SM, Mugge A. $\mathrm{L}$-arginine supplementation in hypercholesterolemic rabbits normalizes leukocyte adhesion to non-endothelial matrix. Life Sci 2000; 66: 1519-24.

22. Böger RH, Sydow K, Borlak J, Thum T, Lenzen H, Schubert B, et al. LDL cholesterol upregulates synthesis of asymmetrical dimethylarginine in human endothelial cells: involvement of S-adenosylmethionine-dependent methyltransferases. Circ Res 2000; 87: 99-105.

23. Ito A, Tsao PS, Adimoolam S, Kimoto M, Ogawa T, Cooke JP. Novel mechanism for endothelial dysfunction: dysregulation of dimethylarginine dimethylaminohydrolase. Circulation 1999; 99: 3092-5.

24. Dimmeler S, Fleming I, Fisslthaler B, Hermann C, Busse R, Zeiher AM. Activation of nitric oxide synthase in endothelial cells by Aktdependent phosphorylation. Nature 1999; 399: 601-5.

25. Fisslthaler B, Dimmeler S, Hermann C, Busse R, Fleming I. Phos- 
phorylation and activation of the endothelial nitric oxide synthase by fluid shear stress. Acta Physiol Scand 2000; 168: 81-8.

26. Vanhoutte PM. Endothelial dysfunction in hypertension. J Hypertens Suppl 1996; 14: S83-93.

27. De Vriese AS, Verbeuren TJ, Van de Voorde J, Lameire NH, Vanhoutte PM. Endothelial dysfunction in diabetes. Br J Pharmacol 2000; 130: 963-74.

28. Vanhoutte PM. Endothelial dysfunction and atherosclerosis. Eur Heart J 1997; 18(Suppl E): E19-29.

29. Vanhoutte PM. Endothelium-dependent responses in congestive heart failure. J Mol Cell Cardiol 1996; 28: 2233-40.

30. Andrawis N, Jones DS, Abernethy DR. Aging is associated with endothelial dysfunction in the human forearm vasculature. J Am Geriatr Soc 2000; 48: 193-8.

31. Haraguchi Y, Takiguchi M, Amaya Y, Kawamoto S, Matsuda I, Mori M. Molecular cloning and nucleotide sequence of cDNA for human liver arginase. Proc Natl Acad Sci U S A 1987; 84: 412-5.

32. Morris SM Jr, Bhamidipati D, Kepka-Lenhart D. Human type II arginase: sequence analysis and tissue-specific expression. Gene 1997; 193: 157-61.

33. Chang CI, Liao JC, Kuo L. Arginase modulates nitric oxide production in activated macrophages. Am J Physiol 1998; 274: H342-8.

34. Koga T, Koshiyama Y, Gotoh T, Yonemura N, Hirata A, Tanihara H, et al. Coinduction of nitric oxide synthase and arginine metabolic enzymes in endotoxin-induced uveitis rats. Exp Eye Res 2002; 75: 659-67.

35. Louis CA, Reichner JS, Henry WL Jr, Mastrofrancesco B, Gotoh T, Mori M, et al. Distinct arginase isoforms expressed in primary and transformed macrophages: regulation by oxygen tension. Am J Physiol 1998; 274: R775-82.

36. Que LG, George SE, Gotoh T, Mori M, Huang YC. Effects of arginase isoforms on NO Production by nNOS. Nitric Oxide 2002; 6: 1-8.

37. Sonoki T, Nagasaki A, Gotoh T, Takiguchi M, Takeya M, Matsuzaki $\mathrm{H}$, et al. Coinduction of nitric-oxide synthase and arginase I in cultured rat peritoneal macrophages and rat tissues in vivo by lipopolysaccharide. J Biol Chem 1997; 272: 3689-93.

38. Modolell M, Corraliza IM, Link F, Soler G, Eichmann K. Reciprocal regulation of the nitric oxide synthase/arginase balance in mouse bone marrow-derived macrophages by TH1 and TH2 cytokines. Eur J Immunol 1995; 25: 1101-4.

39. Morris SM Jr, Kepka-Lenhart D, Chen LC. Differential regulation of arginases and inducible nitric oxide synthase in murine macrophage cells. Am J Physiol 1998; 275: E740-7.

40. Ignarro LJ, Buga GM, Wei LH, Bauer PM, Wu G, del Soldato P. Role of the arginine-nitric oxide pathway in the regulation of vascular smooth muscle cell proliferation. Proc Natl Acad Sci U S A 2001; 98 : 4202-8.

41. Li H, Meininger CJ, Hawker JR Jr, Haynes TE, Kepka-Lenhart D, Mistry SK, et al. Regulatory role of arginase I and II in nitric oxide, polyamine, and proline syntheses in endothelial cells. Am J Physiol Endocrinol Metab 2001; 280: E75-82.

42. Levillain O, Balvay S, Peyrol S. Mitochondrial expression of arginase II in male and female rat inner medullary collecting ducts. J Histochem Cytochem 2005; 53: 533-41.

43. Lim HK, Lim HK, Ryoo S, Benjo A, Shuleri K, Miriel V, Baraban E, et al. Mitochondrial arginase II constrains endothelial NOS-3 activity.
Am J Physiol Heart Circ Physiol 2007; 293: H3317-24.

44. Berkowitz DE, White R, Li D, Minhas KM, Cernetich A, Kim S, et al. Arginase reciprocally regulates nitric oxide synthase activity and contributes to endothelial dysfunction in aging blood vessels. Circulation 2003; 108: 2000-6.

45. White AR, Ryoo S, Li D, Champion HC, Steppan J, Wang D, et al. Knockdown of arginase I restores NO signaling in the vasculature of old rats. Hypertension 2006; 47: 245-51.

46. Hein TW, Zhang C, Wang W, Chang CI, Thengchaisri N, Kuo L. Ischemia-reperfusion selectively impairs nitric oxide-mediated dilation in coronary arterioles: counteracting role of arginase. FASEB J 2003; 17: 2328-30.

47. Zhang C, Hein TW, Wang W, Miller MW, Fossum TW, McDonald MM, et al. Upregulation of vascular arginase in hypertension decreases nitric oxide-mediated dilation of coronary arterioles. Hypertension 2004; 44: 935-43.

48. Johnson FK, Johnson RA, Peyton KJ, Durante W. Arginase inhibition restores arteriolar endothelial function in Dahl rats with saltinduced hypertension. Am J Physiol Regul Integr Comp Physiol 2005; 288: R1057-62.

49. Bivalacqua TJ, Hellstrom WJ, Kadowitz PJ, Champion HC. Increased expression of arginase II in human diabetic corpus cavernosum: in diabetic-associated erectile dysfunction. Biochem Biophys Res Commun 2001; 283: 923-7.

50. Ryoo S, Lemmon CA, Soucy KG, Gupta G, White AR, Nyhan D, et al. Oxidized low-density lipoprotein-dependent endothelial arginase II activation contributes to impaired nitric oxide signaling. Circ Res 2006; 99: 951-60.

51. Ming XF, Barandier C, Viswambharan H, Kwak BR, Mach F, Mazzolai L, et al. Thrombin stimulates human endothelial arginase enzymatic activity via RhoA/ROCK pathway: implications for atherosclerotic endothelial dysfunction. Circulation 2004; 110 : 3708-14.

52. Nelin LD, Wang X, Zhao Q, Chicoine LG, Young TL, Hatch DM, et al. MKP-1 switches arginine metabolism from nitric oxide synthase to arginase following endotoxin challenge. Am J Physiol Cell Physiol 2007; 293: C632-40.

53. Demougeot C, Prigent-Tessier A, Marie C, Berthelot A. Arginase inhibition reduces endothelial dysfunction and blood pressure rising in spontaneously hypertensive rats. J Hypertens 2005; 23: 971-8.

54. Hsu LL, Champion HC, Campbell-Lee SA, Bivalacqua TJ, Manci EA, Diwan BA, et al. Hemolysis in sickle cell mice causes pulmonary hypertension due to global impairment in nitric oxide bioavailability. Blood 2007; 109: 3088-98.

55. Sim JY. Nitric oxide and pulmonary hypertension. Korean J Anesthesiol 2010; 58: 4-14.

56. Hayashi T, Esaki T, Sumi D, Mukherjee T, Iguchi A, Chaudhuri G. Modulating role of estradiol on arginase II expression in hyperlipidemic rabbits as an atheroprotective mechanism. Proc Natl Acad Sci U S A 2006; 103: 10485-90.

57. Steppan J, Ryoo S, Schuleri KH, Gregg C, Hasan RK, White AR, et al. Arginase modulates myocardial contractility by a nitric oxide synthase 1-dependent mechanism. Proc Natl Acad Sci U S A 2006; 103: 4759-64.

58. Nawrath H, Wegener JW, Rupp J, Habermeier A, Closs EI. Voltage 
dependence of L-arginine transport by hCAT-2A and hCAT-2B expressed in oocytes from Xenopus laevis. Am J Physiol Cell Physiol 2000; 279: C1336-44.

59. Rotmann A, Closs EI, Liewald JF, Nawrath H. Intracellular accumulation of L-Arg, kinetics of transport, and potassium leak conductance in oocytes from Xenopus laevis expressing hCAT-1, hCAT-2A, and hCAT-2B. Biochim Biophys Acta 2004; 1660: 138-43.

60. Eisenthal R, Danson MJ, Hough DW. Catalytic efficiency and kcat/ KM: a useful comparator? Trends Biotechnol 2007; 25: 247-9.

61. Topal G, Brunet A, Walch L, Boucher JL, David-Dufilho M. Mitochondrial arginase II modulates nitric oxide synthesis through nonfreely exchangeable L-arginine pools in human endothelial cells. J Pharmacol Exp Ther 2006; 318: 1368-74.

62. Solomonson LP, Flam BR, Pendleton LC, Goodwin BL, Eichler DC. The caveolar nitric oxide synthase/arginine regeneration system for NO production in endothelial cells. J Exp Biol 2003; 206: 2083-7.

63. Ryoo S, Gupta G, Benjo A, Lim HK, Camara A, Sikka G, et al. Endothelial arginase II: a novel target for the treatment of atherosclerosis. Circ Res 2008; 102: 923-32.

64. Miller FJ Jr, Gutterman DD, Rios CD, Heistad DD, Davidson BL. Superoxide production in vascular smooth muscle contributes to oxidative stress and impaired relaxation in atherosclerosis. Circ Res 1998; 82: 1298-305.

65. Suzuki H, Swei A, Zweifach BW, Schmid-Schönbein GW. In vivo evidence for microvascular oxidative stress in spontaneously hypertensive rats. Hydroethidine microfluorography. Hypertension 1995; 25: 1083-9.

66. Griendling KK, Sorescu D, Ushio-Fukai M. NAD(P)H oxidase: role in cardiovascular biology and disease. Circ Res 2000; 86: 494-501.

67. Griendling KK, Minieri CA, Ollerenshaw JD, Alexander RW. Angiotensin II stimulates NADH and NADPH oxidase activity in cultured vascular smooth muscle cells. Circ Res 1994; 74: 1141-8.

68. Seshiah PN, Weber DS, Rocic P, Valppu L, Taniyama Y, Griendling $\mathrm{KK}$. Angiotensin II stimulation of $\mathrm{NAD}(\mathrm{P}) \mathrm{H}$ oxidase activity: upstream mediators. Circ Res 2002; 91: 406-13.

69. Görlach A, Brandes RP, Nguyen K, Amidi M, Dehghani F, Busse R. A gp91phox containing NADPH oxidase selectively expressed in endothelial cells is a major source of oxygen radical generation in the arterial wall. Circ Res 2000; 87: 26-32.

70. Butler R, Morris AD, Belch JJ, Hill A, Struthers AD. Allopurinol normalizes endothelial dysfunction in type 2 diabetics with mild hypertension. Hypertension 2000; 35: 746-51.

71. Harrison DG. Cellular and molecular mechanisms of endothelial cell dysfunction. J Clin Invest 1997; 100: 2153-7.

72. Cooke JP. Is atherosclerosis an arginine deficiency disease? J Investig Med 1998; 46: 377-80.

73. Abu-Soud HM, Feldman PL, Clark P, Stuehr DJ. Electron transfer in the nitric-oxide synthases. Characterization of L-arginine analogs that block heme iron reduction. J Biol Chem 1994; 269: 32318-26.

74. Asmar R, Rudnichi A, Blacher J, London GM, Safar ME. Pulse pressure and aortic pulse wave are markers of cardiovascular risk in hypertensive populations. Am J Hypertens 2001; 14: 91-7.

75. Chobanian AV, Bakris GL, Black HR, Cushman WC, Green LA, Izzo JL Jr, et al. The Seventh report of the joint national committee on prevention, detection, evaluation, and treatment of high blood pressure: the JNC 7 report. JAMA 2003; 289: 2560-72.

76. Collins AJ, Li S, Gilbertson DT, Liu J, Chen SC, Herzog CA. Chronic kidney disease and cardiovascular disease in the Medicare population. Kidney Int Suppl 2003; 87: S24-31.

77. Dart AM, Kingwell BA. Pulse pressure--a review of mechanisms and clinical relevance. J Am Coll Cardiol 2001; 37: 975-84.

78. Miura K, Dyer AR, Greenland P, Daviglus ML, Hill M, Liu K, et al. Pulse pressure compared with other blood pressure indexes in the prediction of 25-year cardiovascular and all-cause mortality rates: The Chicago Heart Association Detection Project in Industry Study. Hypertension 2001; 38: 232-7.

79. Blacher J, Guerin AP, Pannier B, Marchais SJ, Safar ME, London GM. Impact of aortic stiffness on survival in end-stage renal disease. Circulation 1999; 99: 2434-9.

80. Chae CU, Pfeffer MA, Glynn RJ, Mitchell GF, Taylor JO, Hennekens $\mathrm{CH}$. Increased pulse pressure and risk of heart failure in the elderly. JAMA 1999; 281: 634-9.

81. Fukuhara M, Matsumura K, Ansai T, Takata Y, Sonoki K, Akifusa S, et al. Prediction of cognitive function by arterial stiffness in the very elderly. Circ J 2006; 70: 756-61.

82. Kostis JB, Lawrence-Nelson J, Ranjan R, Wilson AC, Kostis WJ, Lacy CR. Association of increased pulse pressure with the development of heart failure in SHEP. Systolic Hypertension in the Elderly (SHEP) Cooperative Research Group. Am J Hypertens 2001; 14: 798-803.

83. Safar ME, Blacher J, Mourad JJ, London GM. Stiffness of carotid artery wall material and blood pressure in humans: application to antihypertensive therapy and stroke prevention. Stroke 2000; 31: 782-90.

84. Najjar SS, Scuteri A, Lakatta EG. Arterial aging: is it an immutable cardiovascular risk factor? Hypertension 2005; 46: 454-62.

85. Ferrier KE, Muhlmann MH, Baguet JP, Cameron JD, Jennings GL, Dart AM, et al. Intensive cholesterol reduction lowers blood pressure and large artery stiffness in isolated systolic hypertension. J Am Coll Cardiol 2002; 39: 1020-5.

86. Toikka JO, Niemi P, Ahotupa M, Niinikoski H, Viikari JS, Ronnemaa $\mathrm{T}$, et al. Large-artery elastic properties in young men: relationships to serum lipoproteins and oxidized low-density lipoproteins. Arterioscler Thromb Vasc Biol 1999; 19: 436-41.

87. Wang YX, Halks-Miller M, Vergona R, Sullivan ME, Fitch R, Mallari $\mathrm{C}$, et al. Increased aortic stiffness assessed by pulse wave velocity in apolipoprotein E-deficient mice. Am J Physiol Heart Circ Physiol 2000; 278: H428-34.

88. Chowienczyk PJ, Watts GF, Cockcroft JR, Ritter JM. Impaired endothelium-dependent vasodilation of forearm resistance vessels in hypercholesterolaemia. Lancet 1992; 340: 1430-2.

89. Sudhir K, Mullen WL, Hausmann D, Fitzgerald PJ, Chou TM, Yock PG, et al. Contribution of endothelium-derived nitric oxide to coronary arterial distensibility: an in vivo two-dimensional intravascular ultrasound study. Am Heart J 1995; 129: 726-32.

90. Fitch RM, Vergona R, Sullivan ME, Wang YX. Nitric oxide synthase inhibition increases aortic stiffness measured by pulse wave velocity in rats. Cardiovasc Res 2001; 51: 351-8.

91. Peng X, Haldar S, Deshpande S, Irani K, Kass DA. Wall stiffness suppresses Akt/eNOS and cytoprotection in pulse-perfused endothelium. Hypertension 2003; 41: 378-81.

92. Poli A, Tremoli E, Colombo A, Sirtori M, Pignoli P, Paoletti R. Ultrasonographic measurement of the common carotid artery wall thickness in hypercholesterolemic patients. A new model for the quantitation and follow-up of preclinical atherosclerosis in living 
human subjects. Atherosclerosis 1988; 70: 253-61.

93. O'Leary DH, Polak JF, Kronmal RA, Manolio TA, Burke GL, Wolfson SK Jr. Carotid-artery intima and media thickness as a risk factor for myocardial infarction and stroke in older adults. Cardiovascular Health Study Collaborative Research Group. N Engl J Med 1999; 340: 14-22.

94. Allan PL, Mowbray PI, Lee AJ, Fowkes FG. Relationship between carotid intima-media thickness and symptomatic and asymptomatic peripheral arterial disease. The Edinburgh Artery Study. Stroke 1997; 28: 348-53.

95. Blankenhorn DH, Selzer RH, Crawford DW, Barth JD, Liu CR, Liu $\mathrm{CH}$, et al. Beneficial effects of colestipol-niacin therapy on the common carotid artery. Two- and four-year reduction of intimamedia thickness measured by ultrasound. Circulation 1993; 88: 20-8. 